\title{
Tanzania in the face of international trade: the analysis of revealed comparative advantage from 2009 to 2012
}

\author{
Nuran Ally Mwasha', Zabibu Kweka² \\ ${ }^{1}$ School of Economics \& Business Administration, Central China Normal University, Wuhan, China \\ ${ }^{2}$ College of Information Management, Central China Normal University, Wuhan, China
}

Email address:

nuranally@yahoo.com (N. A. Mwasha), zabibukweka@gmail.com (Z. Kweka)

\section{To cite this article:}

Nuran Ally Mwasha, Zabibu Kweka. Tanzania in the Face of International Trade: The Analysis of Revealed Comparative Advantage from 2009 to 2012. International Journal of Business and Economics Research. Vol. 3, No. 1, 2014, pp. 15-28. doi: $10.11648 /$ j.ijber.20140301.13

\begin{abstract}
Tanzania is the most promising current and the destination market for the world trade due to its copious resources and strategic location. It is well known in the region as the trade hub as it provides the influential and suitable trade solutions and investments. The aspiration of this paper is to analyse the Revealed Comparative Advantage (RCA) for the topmost export sectors and commodities in Tanzania from 2009 to 2012 by inspecting and evaluating its potency and competence in the world market compared to exports from other countries. Balassa's index of Comparative advantage (RCA) was utilized to demonstrate the competitive sectors and commodities comparative advantage together with export data from UN com-trade and International Trade Centre (ITC). The outcomes show that Tanzania has significantly strong comparative advantages in sectors of traditional cash crops such as coffee, tea and spices and commodities found in mineral resources as the leading export sector and commodities for the period of four years with RCA greater than one. However, many sectors demonstrated lower RCA compared to individual commodities and the export products have been waning every year, the situation that needs the government to initiate the immediate measures to overcome such problem.
\end{abstract}

Keywords: Revealed Comparative Advantage, Export Processing Zones, Tanzania, International Trade

\section{Introduction}

United Republic of Tanzania (URT) is one amongst African countries in which its economy is growing at a considerable pace accompanied by the greatest resource potentials and enormous investment destinations. It is a union of two countries which are Tanganyika and Zanzibar united in 1964 and formed Tanzania. It is located in East Africa bordered by Zambia, Mozambique and Malawi to the South, Uganda and Kenya in the North, Burundi, Rwanda and Democratic Republic of Congo to the West and Indian Ocean in the East which covers $800 \mathrm{~km}^{2}$ coastal lines. Tanzania has a land area of 945,000 square $\mathrm{km}$, surpasses all other East African countries (Tanzania National Trade Policy (TNTP), 2003: 4 \& Wangwe, 1996), comprise of 62,000 square $\mathrm{km}$ for inland water bodies and 3,350 square $\mathrm{km}$ of woodlands and forest. According to URT (2007) cited by Lange, (2008), Tanzania has a land surface area of 94.3 million hectors with one-fourth reserves land, a portion which is considered to be bigger than any other sub-Saharan Africa, 5.1 million hectares are cultivated and 10 million hectares of arable land which is not cultivated. According to the National Bureau of Statistics of Tanzania (2013), the population and housing census of 2012, Tanzania has $44,928,923$ people, which ensures the accessibility of adequate manpower for production and consumption for both internal and external products.

Tanzania is the emerging market in East and Central African region as it provides the commercial links with the assortment of well allocated communication and transportation network together with firmly established economic infrastructures (TIC, 2013). According to the Ministry of Transportation in Tanzania (MOT) (2011), $85 \%$ of international business is depending much on marine transportation which involves inland and seaports. Tanzania provides natural access through different ports like a Dar es Salaam seaport which is the biggest and it facilitates the exportation and importation of commodities and products in Tanzania. According to Ministry Of Agriculture, Food Security and Cooperatives MAFSC (2009: 4) "It has built-in aptitude of dry bulk cargo of $3.1 \mathrm{mn}$ tonnes of containerized cargo and 6.0 tons of bulk liquid”. Other ports are Tanga and 
Mtwara seaports. In 2012, the Dar es Salaam port reported to handle a total volume of $12.1 \mathrm{~m}$ tones and the government expecting to invest $\$ 1.5$ billion for refurbishing and constructing new facilities and port infrastructures (Portstrategy, 2013).

On the other hand, Tanzania has three great lakes which are Victoria, Tanganyika and Nyasa which open the links with neighboring countries like Uganda, Democratic Republic Of Congo, Zambia, Rwanda, Burundi, Malawi and other neighboring states. About aviation industry, Tanzania has three main airports which are Julius Nyerere International Airport (JNIA), Zanzibar International Airport (ZIA) Kilimanjaro International Airport (KIA). Together with other small/local airports within the regions more than 50 (MAFSC, 2009: 3) receiving International and domestic flights, it has facilitated and increase the trade movement within and out of the country which opened up Tanzania to the external world. Furthermore, Tanzania has endowed with the enormous natural resources, including, among others, are minerals like gold, diamond, Tanzanite, copper and coal together with oil and gas (TIC, 2013 \& MAFSC, 2009). Through all these opportunities with political stability, vastly growing population, plentiful natural resources and its geographical location, makes Tanzania to be a precise podium for intensifying business opportunities in all regions.

The specific objective of this paper is to analyse the comparative advantage that Tanzania has in different sectors and commodities in the world market from 2009 to 2012. This period was selected because of the two main reasons;

i. This is the period where the global market was in a recovery situation after the global economic crisis of 2008, (Jurčić \&Teodorović, 2011; Foxley, 2009 \& Lunogelo et al, 2010).

ii. Is the best period to evaluate the objectives of Export Processing Zones (EPZs) Act, which was established in Tanzania in 2002, and to be amended on 2006 to fortify and administering program. According to URT, EPZA (2006), EPZs aimed to attract and encourage investment for export, hearten technological shift, boost the overseas exchange earnings and to generate the employment.

Moreover, this paper is going to provide a brief economic situation from 1979 up to date and different measures taken by the government to solidify economic performance like the economic reforms from 1986 to 2000, its participation and value in international trade, Tanzania comparative advantage analysis and recommendations for future research.

\subsection{Tanzania Economic Situation and Reform}

\subsubsection{General Economic Performance}

Five years before the economic reform in 1986, is known as the crisis period whereby the government undergone highly trade imbalance, export decline, foreign inflow decreased considerably together with devaluation of $15 \%$, after its involvement in war with Uganda (Wangwe, 1996 \&
Wobst, 2001). To unveil from that situation, Bigsten and Danielsson (1999) claimed that, the government initiated different strategies and programs like in 1981-82, National Survival, Economic Program was launched, followed by Structural Adjustment Program (SAP) 1982/83-1985, Economic Recovery Program (ERP) 1986- 1989, and Economic and Social Action Program, (ESAP) in 1989-1991/92 [ibid]. Prior to ERP the established programs did not unravel the pertinent issues which were expected such as accelerating economic growth by efficiently allocates the resources, liberalization of markets for agricultural and overvaluation of the exchange rate. (Also see the African Development Fund, 2007; Brylinsky, 1996)

\subsubsection{Economic Reform 1986 - 2000}

Tanzania has been undergone diverse economic reforms so as to suit the domestic and international business atmosphere. This has been resolutely influenced by the dynamic business environments which are attributed to technological innovations and investments. The economic reform in Tanzania commenced with 'Economic Recovery Program (ERP) of 1986-1989, which its main objective was to re-establish the external and internal equilibrium in the country's economy while specifically, it's aimed at amalgamating the exchange rate, remove the hindrance in trade, inspiring the domestic serving, reinstate fiscal sustainability and bracing exports (Wobst, 2001: Bigsten \& Danielsson, 1999 \& Wangwe, 1996). The program achieved among its priority targets by succeeding to renew up the Structural Adjustment Program with IMF from 1987-1990 (Bigsten \& Danielsson, 1999: 15). The economic reform started to get a new impulse from 1995 when the government re-establish and request different world donors to support Tanzanian economy. In response to that, the government inquires the assistance from the International Monetary Fund (IMF) to establish the Enhanced Economic Recovery Program, which finally named as the Poverty Reduction and Growth Facility in 1996/1997 and 1998/1999 (Bigsten \& Danielsson, 1999 \& Wobst, 2001).

On the other hand, it's continuous to receive more economic assistance in 2000 when its debt was reduced after IMF and International development Association agreed to do so under the Enhanced Indebted Poor Countries [Ibid]. Beside so many challenges to achieve the economic reform objectives, it enhanced per capita increase up to 0.6 percent annually, increased agriculture and manufacturing sector productivity, export commenced to return to its normal situation, broadened the domestic and international trade and improvement of construction industries. Supporting this argument, African Economic Outlook (2002) argues that, the economic reform reinstated macroeconomic stability after the enhancement of the fiscal condition led to downsizing the inflation rate, stabilize the exchange rate and dilapidated the borrow rates. Also in the year 2000, the industrial sector grows to $6.7 \%$ from $5.5 \%$ in $1999,4.8 \%$ increase in manufacturing productivity, the service sector widened its service for $6.4 \%$ compared to $1.8 \%$ in 1999 and 
the whole revenue increased from $14 \%$ of GDP in 1999 to $15.3 \%$ in 2000 [Ibid].

Currently, the World Bank and other donors are still providing monetary assistance to Tanzania to gear up her effort to reach the millennium goals include among others poverty reduction and education for all. Tanzania received the world's largest Millennium Challenge Compact Grant about $\$ 698$ million in 2008 (CIA World Fact book, 2014). Through the government efforts and assistance from international donors, Tanzania has been able to solidify its economic infrastructures by increasing GDP, Purchasing Power Parity (PPP) from estimated $\$ 64.23$ billion in 2010 to $\$ 73.12$ billion in 2012, and the increase of GDP from $6 \%$ 2009 to $6.9 \% 2012$ [Ibid].

\subsection{Literature Review}

\subsubsection{Tanzania and the International Trade}

The international trade has played a great role in the improvement and economic prosperity of many countries including Tanzania. In one way or another, countries have been influenced much by economic activities taking place in other country either through business, technology transfer, investments or human capital. This is because when the countries' trade to each other there is common benefits gathered from that trade, often called gain from trade (Krugman \& Obstfeld, 2006 \& 2005: 17). However, there are some people who are sceptical about gaining from trade considering technological and economic variations that one country may benefit more than another [Ibid]. The potentials of international trade not only provide the opportunity for the countries to specialize in a specific product which can be efficiently produced to a large extent, but also allows international borrowing, lending and exchange of international stocks and bonds that allows the counties to expand their economic welfare (Dixit \& Norman, 2002; Krugman \& Obstfeld, 2006 \& Hill, 2008).

\subsubsection{International Trade Theories}

For any business to succeed, theories are very important as they provide guideline and answers of significant questions like why to trade, which kind of goods and services can be traded and how it can be beneficial for each participant. There are several theories of international trade that analyses different issues on trade by providing critical issues on trade liberalization. By explaining few among others, Smith (1776) in his absolute advantage theory argues that, a country should never produce goods that it can buy cheaply in another country, and it should specialize in the production of goods that has an absolute advantage than other country, and trade them with goods from other nations (Hill, 2008:48 \& Pugel, 2005). This means that by specializing in goods that every country has an absolute advantage, it will make both of them to gain well in trade by maximizing production for domestic and international market. Another important theory is Comparative Advantage theory by David Ricardo, (1817) which states that, it is better for the country to specialize in the production of goods which it can produce far more efficient and buy from other countries goods that it is less efficient in production. This will make both countries to maximize their production by increasing output and make their consumers pay less and utilize more for both goods (Hill, 2008: Chingarande et al, 2013; Krugman \& Obstfeld, 2006: Pugel, 2005 \& Mzumara et al, 2012). The Ricardian theory has been supported much by Hecksher-Ohlin who offers much evidence, considering the factor endowment, a country is considerably of high comparative advantage if it exploit well its obtainable resources (Widgren, 2005 as cited by Mzumara et al, 2012). Comparative Advantage of a nation as it is characterized by free trade is more affected by National trade policies which can favor exports and limit imports from others and import duties on trade (Pugel, 2005; Hill, 2008:106 \& Krugman \& Obstfeld, 2006)

With reference to different studies, like Pearson \& Meyer (1974), Eifert, (2005), African Economic Outlook (2002) and Muchanyuri \& Mzumara, (2013), Tanzania have strong comparative advantages in different sectors, but more competitively in agricultural production, tourism and mineral resources. Tanzania is a member of various regional groupings in the world and Africa in particular, which provides her with the greatest opportunity to trade in goods and services to the member states freely. It has been exporting and importing different commodities and products from the partners' market countries, including, among others, to East African countries like Kenya, Uganda, Burundi and Rwanda as their implementation of the EAC Customs Union protocol for the partner states to encourage export amid member states for economic advancement (Isaac \& Athena, 2011 \& MAFSC, 2009). Also Southern African Development Community (SADC) market, which has made the magnificent development in achieving free Trade Area for its member States commenced in 2009, so as to achieve the economic intensification, poverty reduction, establishment of mutual political values and improve the life standard of their people (Mzumara et al, 2012). Other markets are in the World Trade Organization members (WTO), European Union (EU), the Indian Ocean Rim Association for regional Co-operation, African Growth Opportunity Act from United State (AGOA), Chinese Special and Preferential Market Arrangement, Caribbean and Pacific Countries (ACP) and Everything but Arms (EBA-EU) (MAFSC, 2009, TIC, 2013).

The main exports from Tanzania is dominated by agricultural products which provide $85 \%$ of export (CIA World Factbook, 2014 \& Wangwe, 1996), and $25 \%$ Gross Domestic Product (GDP) (MAFSC, 2009: 9) together with mineral resources. According to Economy Watch, (2010) asserted that import and export in Tanzania contributed $61.4 \%$ to the GDP in 2006 to 2008 , while the exports increased from $\$ 2.413$ billion in 2008 to $\$ 2.744$ billion in 2009 , the import dropped from $\$ 7.08$ billion 2008 to $\$ 5.545$ billion in 2009. The total export to European Union in 2008 were $€ 326.29$ million, whereas imports increased from $€ 404.246$ million to $€ 478.246$ million 2008. The export 
sector has been firmly increasing which is accelerated by exportation of gold as it recorded the export of $\$ 8.7$ billion in 2012 , more than $18 \%$ of the recorded percent in 2011 , which was $7.4 \%$, while import had a slightly increment only $\$ 0.7$ billion from $\$ 12$ billion to $\$ 12.7$ billion in 2011 and 2012 respectively (African Economic Outlook, 2013). In 2011 the economy grows at an average rate of $6.4 \%$, while remaining elastic and is catalyzed by manufacturing sectors, agriculture, transport and communication, mining sectors, and currently the discovery of oil and gas about 33 trillion cubic feet, which will lead the country to access more than $\$ 10$ billion to facilitate the investments [ibid].

Therefore, Tanzania export from 2000 to 2012 have been surpassed many countries in the world, including Mauritius, Malaysia, Brazil, Thailand and Tunisia, which make the total merchandise export in 2012 increased to about $\$ 5.2$ billion [ibid].

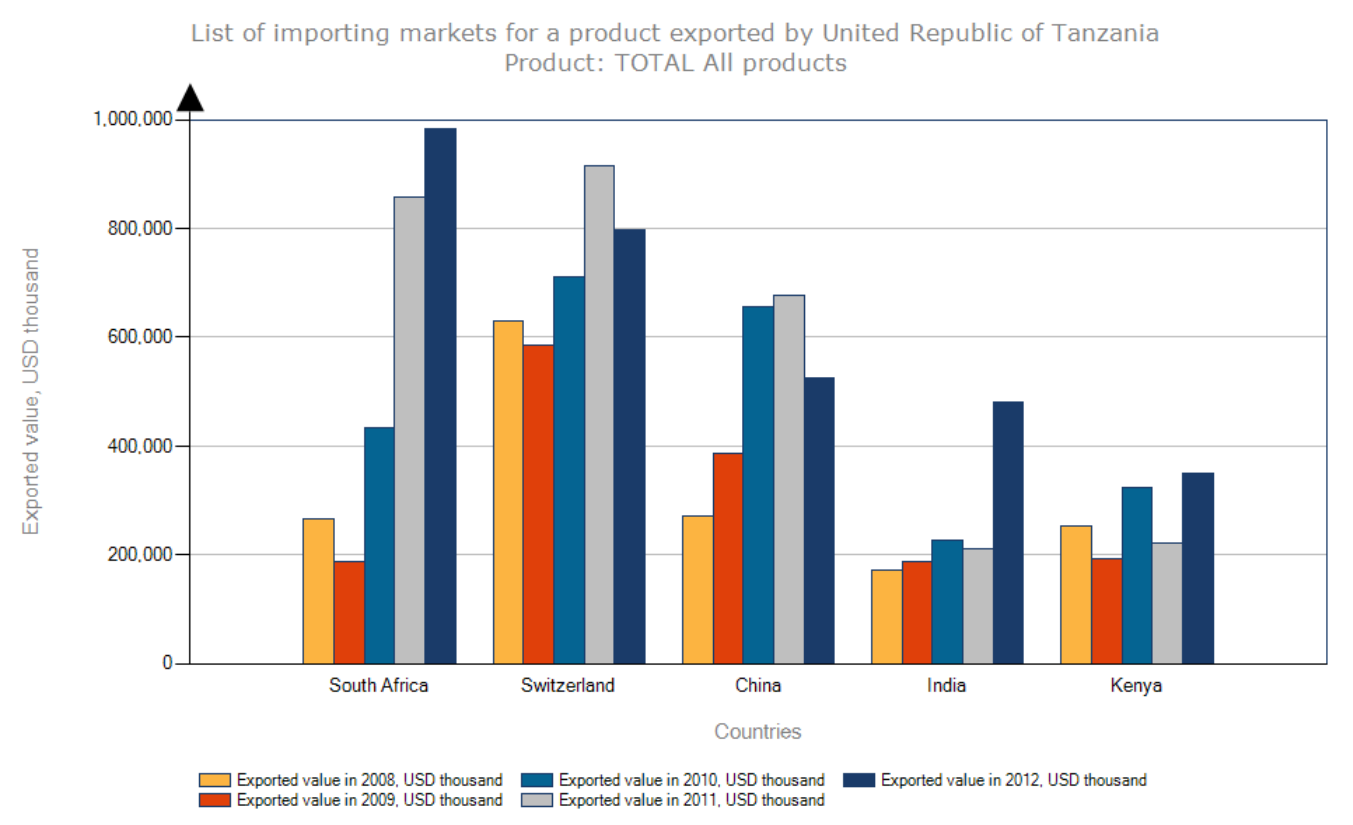

Figure 1. The top 5 Countries received more export products from Tanzania from 2008 - 2012. (Sources: International Trade Centre)

\subsubsection{Revealed Comparative Advantage (RCA)}

As have been already discussed, the country comparative advantage generally depends on the economist views about the trade pattern and production capabilities within a country. In the absence of trade, the comparative advantage is measured indirectly as far as it cannot be discovered by analyzing it by applying the comparative prices ${ }^{1}$. Different scholars have explained the Revealed Comparative Advantage differently, but focusing much on what country is intensively capable of producing by examining the trade model and its productivity. Revealed Comparative Advantage Index refers to the ratio of the country's total export of the high productivity commodity in its total exports and the share of the world exports of the similar commodity in total world export [Ibid]. RCA is a measure of the acquired output by the country in the current trade pattern (Mzumara et al, 2012). It employs the trade patterns to spot out the highly competitive economic sector in the country by evaluating the world average with the country's trade profile. Serin \& Civan, (2008) describe the Balassa Index as a measure of a certain nation, ordinary and preference export portion considering how worth are other nation's exports in the similar industry in the world (more

\footnotetext{
${ }^{1}$ http://www.unescap.org/tid/artnet/RCA.pdf
}

review in Widgren, 2005 \& Batra \& Khan, 2005). It was emanate by Liesner and improved more by Balassa in (1965) as the method and a fabulous technique to analyse and measure the potency and the feeble sectors in the country. In reference to Batra \& Khan, (2005) affirmed that, among the aspects that improves the revealed Comparative Advantage are increased world demand of a certain commodity, alteration in the structure and specialization. Considering the RCA index, meaning the following significances can be depicted such as it assist to recognize good sectors for investments and the commodities of priorities, it is highly qualified for dynamic environment for trade as it reduces wastage of efforts to disadvantageous commodities, led to specialization which is suitable for the competitive market and it shows factors that can cause the trade patterns such as trade policies and factor endowments.

Balassa index has been used by different studies and researches to measure and compare different sectors of economies globally. Chingarande et al, (2013) used RCA to investigate the comparative advantage of East African Community (EAC) member state and their economic performance. It depicted that all member states have RCA, however, in a few products and have well performed economically. Batra \& Khan, (2005), examine the structure of the comparative Advantage of China and India in the world market and realized among other things, there are 
similarities in structure of comparative advantage, although there was no correlation between manufacturing sectors in China and India in the world market. Furthermore Mzumara et al, (2012) has used Balassa RCA index for Southern African Development Community member States, and concluded that, all member states have RCA; however they have fewer products with comparative Advantage. It was also used in Brazil examine 'the source of comparative advantage' by Muriel \& Terra (2009) in two seasons, which found that, Brazil revealed a profusion in land, capital and a shortage of skilled labour. Revealed Comparative Advantage utilized to illustrate China's transformation of its export pattern which indicated the dissimilar exports, amidst inland and the coastal China (Yue, 2001, as cited by Mzumara El al, 2012).

\section{Methodology}

The analysis of this paper is going to use Balassa's index (1965) of RCA, as a reliable technique globally, to examine the comparative advantage in Tanzania sectors and commodities. Arithmetically, the method is as follows;

$$
R C A=\frac{\mathrm{X} i \mathrm{j} / \sum \mathrm{XXij}}{\sum \mathrm{iXij} / \sum \mathrm{i} \sum \mathrm{iXij}}
$$

Whereas; Xij - is the export of product ' $\mathrm{j}$ ' in country ' $\mathrm{i}$ ' $\Sigma \mathrm{iXij}$ - The total export in country ' $\mathrm{i}$ '

$\Sigma \mathrm{j} X \mathrm{ij}-$ The total export of product ' $\mathrm{j}$ ' in the world $\Sigma \mathrm{i} \Sigma \mathrm{jXij}-$ Total export of all product ' $\mathrm{j}$ ' in the world

The description of Balassa's index is as follows; if the country exhibits the RCA greater than one, obviously it will have Revealed Comparative advantage in that product (RCA $\geq 1$ ). And if it displays the Revealed Comparative Advantage less than one ( $\mathrm{RCA}<1$ ), clearly the country will have a comparative disadvantage in that product (Balassa 1965 \& ITC user Guide: 42). "A positive value of the Balassa index indicate that the country is specialized in the selected industry's exports, but does not necessarily mean that this sector contributes positively to the national trade balance" (ITC user Guide: 45).

This paper also has used data from United Nations Commodity Trade Statistics Database (UN Comtrade) to calculate the Tanzanian export data in 2009 and 2012, and to analyse the comparative advantage of the HS 4 digit level. Then It used International Trade Centre (ITC) export data to provide the general account for sectoral performance from 2009 to 2012 .

\section{Analysis and Findings}

\subsection{Sectors and Commodity analysis (Based on ITC Export Data)}

In 2009, Tanzania had 27 sectors with revealed comparative advantage out of 98, comprised of 1616 products exported, whereas 400 products had RCA in the world market. It was led by coffee, tea, mate and spices with RCA of 28.6 , contributed to $15.56 \%$ of all share of the Tanzania RCA and $0.67 \%$ as the share of the world exports. Its export value in the world market is growing up to $26 \%$ per year. The second is vegetable textile fibres nes; paper yam and woven fabric with RCA (28.5), which is $15.50 \%$ for Tanzania RCA and $0.57 \%$ a share of the world exports with its global growing export value of $-11 \%$. The third is ores; slag and ash with RCA (18.3) contribute to $9.95 \%$. In 2010, 32 sectors out of 97 ascribed Tanzania have RCA, whereby it exported a total of 1,703 products to the global market which among them, 473 found to have RCA. The sectors that pioneered the export industry were coffee, a teammate and spices with RCA (17.8), hold about $9.78 \%$ of the total RCA shares in the country, and the global growth in export value of 3\% annually. Ores slag and ash was the second sector contained RCA of (16.5), equals to $9.07 \%$ of all RCA share with the world growing export share of $53 \%$ per year. The third is tobacco and manufactured tobacco substitutes RCA (15.9), contributed about $8.74 \%$ of the Tanzania comparative advantage in the international market.

In 2011, about 1755 products were exported to the global market in which 380 products had RCA. A sector which has highest RCA represented by vegetable textile fibres nes, paper yarn, woven fabric with RCA (19.0) same to $13.5 \%$ of the total Tanzanian RAC, while experiencing the decline of its growing export value for $-2 \%$ per annum. It was followed by coffee, tea, mate and spices with RCA in (17.0) equals to $12.1 \%$ of all RCA which is attributed to the growing value to the world market for $12 \%$ annually. The third commodity that takes pleasure of the global market advantage is the Ores, slag and ash with RCA of (15.5), contribute $11 \%$ of all Tanzania RCA. The year 2012 experience the sudden drop of more that $25 \%$ of the products exported to the world market from 1,755 in 2011 to 1,179 in 2012, and the exported products with RCA dropped to 353 from 380 in 2012. The sectors that have the benefit of the RCA were 27 out of 97, while the leading sector were tobacco and manufactured tobacco substitutes with RCA (63.1) same as $24.2 \%$; coffee, tea, mate and spices RCA (39.3), equals to $15 \%$ of all RCA and the third was vegetable textile fibres nes, paper yam, and woven fabric with RCA of (26.0), equals to $9.97 \%$ of all RCA share in Tanzania.

\subsubsection{Sectors}

There is a substantial variation in performance between sectors. Coffee, tea, mate and spices with HS (09) sector, performed well and lead other sectors for the period of 2009 and 2010 with RCA of 28.6 and 17.8 respectively. Other two periods between 2011 and 2012, the Vegetable textile fibres nes, paper yarn, woven fabric sector (HS. 53) and Tobacco and manufactured tobacco substitutes (HS. 24), share the top position when the (HS 53) lead all sectors at HS 4 digit level in 2011 with the RCA of 19.0 and sector (HS 24) lead to higher performance in 2012 with the RCA of 63.1. 
Table 1. The top three sectors and their potential commodities with highest RCA in each year from 2009-2012.

\begin{tabular}{|c|c|c|c|c|c|c|}
\hline Year & HS Code & Sector description RCA $\geq 1$ & RCA & C. Code & Commodity description RCA $\geq 1$ & RCA \\
\hline \multirow{4}{*}{2009} & 09 & Coffee te mate and snices & \multirow{2}{*}{28.6} & 0909 & Tea & 57.0 \\
\hline & 09 & Conee, tea, male andu spices & & 0901 & Coffee & \multirow[t]{2}{*}{24.1} \\
\hline & 53 & $\begin{array}{l}\text { Vegetable textile fibres nes, paper } \\
\text { yarn, woven fabric }\end{array}$ & 28.5 & 5300 & $\begin{array}{l}\text { (No any commodity portrayed the RCA at Hs } 4- \\
\text { digit level). }\end{array}$ & \\
\hline & 26 & Ores, slag and ash & 18.3 & 2616 & Precious metal ores and concentrates. & 834.5 \\
\hline \multirow{5}{*}{2010} & \multirow[t]{2}{*}{09} & \multirow[t]{2}{*}{ Coffee, tea, mate and spices } & \multirow[t]{2}{*}{17.8} & 0901 & Coffee & 18.1 \\
\hline & & & & & $\begin{array}{l}\text { Tea } \\
\text { Precious metal ores and concentrates }\end{array}$ & 29.3 \\
\hline & 26 & Ores, slag and ash & 16.5 & $\begin{array}{l}2616 \\
2602\end{array}$ & $\begin{array}{l}\text { Precious metal ores and concentrates } \\
\text { Manganese ores and concentrates }\end{array}$ & $\begin{array}{l}379.7 \\
293.7\end{array}$ \\
\hline & \multirow{2}{*}{24} & \multirow{2}{*}{$\begin{array}{l}\text { Tobacco and manufactured tobacco } \\
\text { substitutes }\end{array}$} & \multirow{2}{*}{15.9} & 2401 & Tobacco unmanufactured; tobacco refuse & 45.6 \\
\hline & & & & 2402 & Cigars, cheroots, cigarillos \& cigarettes. & \multirow[t]{2}{*}{2.2} \\
\hline \multirow{5}{*}{2011} & 53 & $\begin{array}{l}\text { Vegetable textile fibres nes, paper } \\
\text { yarn, woven fabric }\end{array}$ & 19.0 & 5300 & $\begin{array}{l}\text { (No any commodity portrayed the RCA at Hs } 4- \\
\text { digit level). }\end{array}$ & \\
\hline & \multirow{2}{*}{09} & \multirow{2}{*}{ coffee, tea, mate and spices } & \multirow{2}{*}{17.0} & 0901 & Coffee & 15.5 \\
\hline & & & & 0902 & Tea & 24.8 \\
\hline & \multirow{2}{*}{26} & \multirow{2}{*}{ Ores, slag and ash } & \multirow{2}{*}{15.5} & 2616 & Precious metal ores and concentrates & 381.0 \\
\hline & & & & 2602 & Manganese ores and concentrates & 336.3 \\
\hline \multirow{3}{*}{2012} & 24 & $\begin{array}{l}\text { Tobacco and manufactured tobacco } \\
\text { substitutes }\end{array}$ & 63.1 & 2401 & Tobacco unmanufactured; tobacco refuse & 188.1 \\
\hline & 09 & Coffee, tea, mate and spices. & 39.9 & $\begin{array}{l}0901 \\
0902\end{array}$ & $\begin{array}{l}\text { Coffee } \\
\text { Tea }\end{array}$ & \multirow[t]{2}{*}{$\begin{array}{l}35.0 \\
44.7\end{array}$} \\
\hline & 53 & $\begin{array}{l}\text { Vegetable textile fibres nes, paper } \\
\text { yam, and woven fabric }\end{array}$ & 26.0 & $5300^{*}$ & $\begin{array}{l}\text { (There is no any commodity portrayed the RCA } \\
\text { at Hs 4- digit level). }\end{array}$ & \\
\hline
\end{tabular}

Source: International Trade Centre database

Note:C. Code - Commodity code; 5300* - All commodities in Vegetable textile fibres nes, paper yam, and woven fabric do not show its RCA at Hs 4-Digit level.

Referring to table 1, illustrate the export performance in top three sectors and its constituent commodities with RCA greater than $1(\mathrm{RCA} \geq 1)$ since 2009 to 2012 . Column one from the page right side show the period (year) from which the RCA was calculated while column two it is the Harmonized System (HS) it have been used to classify different products (ITC User guide: 3), then column 3 it contain different sectors, column four is RCA for sectors, column five is commodity code (special number to describe each commodity), column 6 are the commodity with RCA equal or greater than one and the last column is RCA for commodities available in each sector.

For the whole periods from 2009 - 2012, sector, which portrayed the strongest and the highest performance was Tobacco and manufactured tobacco substitutes with RCA in 63.1 above the minimum which is one (1). There was no a considerable change for these leading sectors RCA since 2009 to 2012, as most of them plummeted or hoist one position. However, the main changes have been observed in the value of RCA, as many sectors lose their comparative strength as time elapsed. Example, coffee, tea, mate and spices which performed well at the beginning, its RCA showed the beg off value for three years consecutively as it drops for about 40.5\% from 28.6, 17.8 and 17 in 2009, 2010 and 2011 respectively. Also, vegetable textile fibres nes, paper yarn and woven fabric, decreased from RCA from 28.5 in 2009 to RCA 26.0 in 2012 about $8.7 \%$. Ores, slag and ash, its RCA value decline decisively from RCA of 18.3 in 2009 to RCA 15.5in 2011, and disappear in top three sectors with high RCA completely in 2012 . The only sector that demonstrated the positive trend in two consecutive periods is 'Tobacco and manufactured tobacco substitutes', emerged in top three in 2010 with the RCA of 15.9 rise to RCA of 63.1 in 2012.

\subsubsection{Commodities}

On the side of commodities, every sector enclosed dissimilar commodities which in one way or another it can contribute to the strength or weakness of the sectors in the world market. However, each commodity can as well stand itself from the competition with other related commodities in the international trade. Many commodities hold by different sectors reveal high performance in terms of RCA. According to the analysis, the commodity (HS 2616), precious metal ores and concentrates ranked in the top position with the highest RCA of 834.5 followed closely by manganese ores and concentrates with RCA of 336.3; Tobacco unmanufactured, tobacco refuse RCA of 188.1; Tea RCA 57; Coffee with RCA 35.0 and Cigars, cheroots, cigarillos \& cigarettes with RCA 2.2. Other sectors like vegetable textile fibres nes, paper yam, and woven fabric which its commodities range between the (HS 5300) to (5311), it did not show their RCA although in its aggregate level it performed well.

As it was in different sectors, also the commodity competence in the global market show a discrepancy in reference to time. Many commodities RCA values were not retained and other commodities experienced a performance slump with time. Example, tea and coffee had RCA of 57.0 and RCA 24.1 in 2009 which dropped to RCA 15.5 and 24.8 in 2011 before it rose again to RCA 35.0 and RCA 44.7. Precious metal ores and concentrates RCA value decreased from 834.5 in 2009 to 381.0 , in 2011 before it fades away in top three competitive commodities entirely by 2012 . 
Manganese ores and concentrates together with tobacco unmanufactured; tobaccos refuse is among the few commodities that experience a positive RCA trend in 2010 and 2011, where it hold an RCA to 293.7 and RCA of 45.6 lastly rose to RCA 336.3 and RCA 188.1 during 2011/2012. Cigars, cheroots, cigarillos \& cigarettes in tobacco and manufactured tobacco substitutes sector, appeared once in top two competitive commodities with RCA greater or equal to one and then undergo performance ineffectiveness afterward.

\subsection{Commodity Analysis (Based on UN Comtrade)}

\subsubsection{Commodity Performance}

Individual commodities played a great role in export industries in Tanzania and are significantly kept growing as the investments in the country is mounting. Some of the commodities have higher RCA while others have lower, although their export value is big enough. For the period since 2009 to 2012, some commodities maintained their status for both RCA and their export value while others decline considerably and shift from the top ten export commodities transported in the global market. In all years, gold, non-monetary (Excl. Gold, ores Concentrate) (HS 9710) hold the first position in export values from Tanzania to the world market, followed by Metalliferous ores and metal scrap (HS 2891). Other Commodities which reserved its export status for about $75 \%$ were power-generating machinery and equipment (HS 711), textile fibres (HS 2631), tobacco and tobacco manufactures (HS 1212) and sesame (Sesamum) seed weight (HS 2225).

Nevertheless, since 2009, the (HS 9710) RCA value decreased in unprecedented rate from RCA 28.01 in 2009 to RCA 20, in 2012. The plunge of gold export in the global market, which contribute to $35 \%$ of Tanzania export earnings in recent years had never been experienced excessively since 1981 (Jerving, 2013), which dropped from $3 \%$, from $\$ 2.24$ billion in 2011 to $\$ 2.17$ billion in 2012 (Bariyo, 2013).

The same case to Metalliferous ores and metal scrap with HS (2891), twine and cordage with (HS 6575) and Sesame (Sesamum) with (HS 2225) seed, which its RCA and its export value decreased from RCA 693.95, RCA 53.75 and RCA 171.77 in 2009 to RCA 181.87, 7.14 and RCA 112.75 in 2012 respectively. The decline in the export competence and RCA for some products / commodities did not encounter merely by the commodities existed in the export industry for a long time, but also bumped into the new emerged commodities like Metalliferous with ores and metal scrap with (HS 2877) and Oth none-ferr metal waste with (HS 2882), which its value dropped from RCA 320.25 and RCA 15.24 in 2010 to RCA 79.52 and 0.93 in 2012.

Table 2. RCA for the top ten Commodities exported to the World Market from 2009- 2012.

\begin{tabular}{|c|c|c|c|c|c|c|c|c|c|}
\hline $\begin{array}{l}\text { Commodity description } \\
\text { (Comm. description.) }\end{array}$ & C. Code & $\begin{array}{l}\mathrm{RCA} \\
2009\end{array}$ & $\begin{array}{l}\text { World } \\
\text { Rank** }\end{array}$ & $\begin{array}{l}\mathrm{RCA} \\
2010\end{array}$ & $\begin{array}{l}\text { World } \\
\text { Rank }\end{array}$ & $\begin{array}{l}\mathrm{RCA} \\
2011\end{array}$ & $\begin{array}{l}\text { World } \\
\text { Rank }\end{array}$ & $\begin{array}{l}\text { RCA } \\
2012\end{array}$ & $\begin{array}{l}\text { World } \\
\text { Rank }\end{array}$ \\
\hline $\begin{array}{l}\text { Gold, non-monetary (Excl. } \\
\text { gold, ores Concentrates) }\end{array}$ & 9710 & 28.01 & $25 / 124$ & 23.24 & $29 / 123$ & 27.455 & $26 / 122$ & 20.88 & $28 / 113$ \\
\hline $\begin{array}{l}\text { Metalliferous ores and metal } \\
\text { scrap }\end{array}$ & 2891 & 693.95 & $2 / 59$ & 416.68 & $4 / 61$ & 299.09 & $5 / 70$ & 181.87 & $7 / 70$ \\
\hline $\begin{array}{l}\text { Power-generating machinery } \\
\text { and equipment }\end{array}$ & 711 & 49.83 & $79 / 114$ & 45.68 & $85 / 112$ & 53.01 & $110 / 116$ & 60.40 & $106 / 108$ \\
\hline $\begin{array}{l}\text { Special transaction not } \\
\text { Classified }\end{array}$ & 9310 & 0.346 & $96 / 164$ & 0.617 & $114 / 158$ & 0.065 & $112 / 152$ & 0.473 & $95 / 136$ \\
\hline $\begin{array}{l}\text { Tobacco and tobacco } \\
\text { manufactures }\end{array}$ & 1212 & 44.25 & $16 / 95$ & 49.46 & $14 / 99$ & 39.503 & $14 / 87$ & 59.66 & $11 / 87$ \\
\hline Textile fibres & 2631 & 45.90 & $12 / 93$ & 19.08 & $19 / 97$ & 9.85071 & $23 / 94$ & 20.59 & $14 / 91$ \\
\hline $\begin{array}{l}\text { Medicinal and pharmaceutical } \\
\text { products }\end{array}$ & 542 & 0.766 & $91 / 151$ & 1.035 & $101 / 144$ & 0.729 & $104 / 141$ & 0.922 & $98 / 129$ \\
\hline $\begin{array}{l}\text { Textile yarn, fabrics, made-up } \\
\text { articles, n.e.s. etc }\end{array}$ & 6585 & 1.032 & $20 / 137$ & 33.99 & $15 / 139$ & 27.17 & $21 / 136$ & 18.71 & $20 / 125$ \\
\hline Twine, cordage etc & 6575 & 53.75 & $23 / 140$ & 79.63 & $48 / 137$ & 15.24 & $39 / 134$ & 7.143 & $43 / 124$ \\
\hline $\begin{array}{l}\text { Sesame(Sesamum) seed } \\
\text { NEW }\end{array}$ & 2225 & 171.77 & $6 / 102$ & 83.08 & $9 / 106$ & 131.91 & $5 / 103$ & 112.75 & $5 / 94$ \\
\hline $\begin{array}{l}\text { Metalliferous ores and metal } \\
\text { scrap }\end{array}$ & 2877 & & & 320.25 & $4 / 60$ & 447.88 & $3 / 61$ & 79.52 & $5 / 55$ \\
\hline Oth. Non-ferr. mental waste & 2882 & & & 15.24 & $38 / 141$ & 1.018 & $81 / 136$ & 0.933 & $87 / 126$ \\
\hline Copper ores and concentrates & 2831 & & & & & & & 19.76 & $17 / 66$ \\
\hline
\end{tabular}

Source: Calculated from UN Comtrade Export data

** - The numerator represents the position of Tanzania among other countries which export the same commodity or product, and denominator represent total number of all countries exported that commodity.

Table 2, show the RCA of the top 10 commodities exported from Tanzania to the world market from 2009 to 2012, evaluating its competence and stability in the market, it shows that the commodity that lost its competitive advantagetheyhe emerged and the one which maintained its position. First column describe the commodity exported from Tanzania to the world market, second column show the commodity codes to identify the commodity, third is commodity RCA for 2009, the forth column show the export position or rank hold by that commodity/product in world 
market, fifth column shows the RCA of all commodities in 2010 , sixth is its position in the world market, seventh RCA for 2011, eighth column is position of product in 2011, ninth column is commodity RCA in 2012 and column 10 is the rank for commodities exported in 2012.

\subsubsection{RCA Variation (RCA Movement)}

Another important and noticeable point is that, there is a decline of export of many commodities in the two years successively, which is 2009 and 2010 and some up to 2011, while show the sudden recovery in 2012 . This can be seen through different product performance as follows; Gold, non-monetary (Excl. gold, ores. Concentrate), metalliferous ores and metal scrap, Twine, cordage and Sesame (Sesamum) seed, fall in total average of $45.1 \%$. At the same time, others enjoyed the comparative ability in the global market. Example tobacco and tobacco manufactures (HS 1212), rose from RCA 44.25 to 49.46 an increment of $10.5 \%$; textile yarn, fabrics, made-up articles n. e. S RCA 1.03 to 33.99 , same as a $96.9 \%$ increase; twine and cordage RCA 53.75 to RCA 79.63 accounted for an increment of $12.1 \%$ and medicinal and pharmaceutical products RCA 0.76 to RCA 1.03 , equals to the increase of $26.2 \%$.

Table 3. The RCA movement for sectors and commodities in Tanzania in 2009-2012

\begin{tabular}{|c|c|c|c|c|c|}
\hline A. & Sectors that gained RCA & $\mathbf{R C A} \geq 1$ & A. & Commodities that gained RCA & $\mathbf{R C A} \geq 1$ \\
\hline 1. & coffee, tea, mate and spices & $28.6-39.9$ & 1. & Power-generating machinery and equipment & $49.8-60.4$ \\
\hline \multirow[t]{2}{*}{2.} & Tobacco and manufactured tobacco substitutes & $15.9-63.1$ & 2. & Tobacco and tobacco manufactures & $44.2-59.6$ \\
\hline & & & 3. & Textile yarn, fabrics, made-up articles, n.e.s. etc & $1.0-18.7$ \\
\hline B. & Sectors that lost the RCA & & B. & Commodities that lost RCA & \\
\hline 1. & $\begin{array}{l}\text { Vegetable textile fibres nes, paper yarn, woven } \\
\text { fabric }\end{array}$ & $28.5-26.0$ & 1. & Gold, non-monetary (Excl. gold, ores Concentrates) & $28-20.8$ \\
\hline \multirow[t]{4}{*}{2.} & Ores, slag and ash & $18.3-15.5$ & 2. & Metalliferous ores and metal scrap & $693.9-181.8$ \\
\hline & & & 3. & Twine, cordage etc & $53.75-7.14$ \\
\hline & & & 4. & Sesame(Sesamum) seed & 171.7-112.7 \\
\hline & & & & Textile fibres & $45.9-20.5$ \\
\hline C. & New sectors emerged & & C. & New Commodities that emerged and gain & \\
\hline \multirow[t]{4}{*}{1.} & Tobacco and manufactured tobacco substitutes & $15.9-63.1$ & & & \\
\hline & & & D. & New Commodities that emerged and lost & \\
\hline & & & 1. & Metalliferous ores and metal scrap & $320.2-79.5$ \\
\hline & & & 2. & Oth. Non-ferr. mental waste & $15.2-0.93$ \\
\hline \multirow[t]{3}{*}{ D. } & Sectors with Comparative disadvantage $* *$ & & E. & Commodities with comparative disadvantage & \\
\hline & & & 1. & Medicinal and pharmaceutical products & 0.92 \\
\hline & & & 2. & Special transaction not Classified & 0.47 \\
\hline
\end{tabular}

** There was no any sector in top three with comparative disadvantage Source: It was made using data from ITC

Table 3 above portrays the RCA movement for both sectors and commodities from 2009 to 2012. Column 1 shows the sectoral numbers in a specific category which is labelled by letter A-D, column 2 are the sectors, column three shows increase or decrease in sectors RCA, column four are the numbers and letters for commodities in a special category, column five are the commodities and column six represent the increase or decrease of RCA.

The commodities which showed quick recovery and rise in 2011 and 2012 were Power-generating machinery and equipment (HS 711), raised from RCA 53.01 to 60.40; Textile fibres (HS 2631) grow up from RCA of 9.8 to RCA 20.59 and Tobacco and tobacco manufactures (HS 1212), increased from RCA 39.50 to RCA 59.66. The main reason for these increments is the assurance from its guaranteed AGOA market in the USA which by 2011 Tanzania exported goods valued $\$ 5.7$ million including tobacco (Daily News, $2013)^{2}$.

It has been discovered that, some commodities have great values in the world export, but contain fewer or less than one RCA in the world market. Some commodities appeared in

\footnotetext{
${ }^{2}$ http://www.dailynews.co.tz/index.php/features/21329-tobacco-cashew-nuts-ta nzania-s-potential-agoa-export-bailout.
}

the top most export lists in Tanzania contained more than 800 commodities while have very small or less than one RCA. Examples of these commodities are 'Medicinal and pharmaceutical products (HS 542)' which hold the tenth (10) position in export value and 'Special transactions and commodities not classified according to kind (HS 9310)', hold fourth position with RCA of 0.76 and RCA 0.34 in 2009 , which remained beneath the required RCA until 2012, having RCA of 0.92 and RCA 0.47 , and hold the eighth (8) and twelfth (12) position respectively. A commodity which grips the maximum number of RCA also depicted the strength of that commodity in the world market towards others in the related industry where Metalliferous ores and metal scrap with the total average of RCA 397.89 followed by sesame (Sesamum) seed with RCA of 124.87 and the third is power generating machinery and equipment with RCA of 52.23.

\subsection{Sectors with Comparative Disadvantage}

In reference to ITC export data 2009 to 2012, there are some other sectors with RCA less than 1 but some of its constituent commodities reveal a comparative advantage in the world market. By mentioning, include, among others, are Ships, boats and other floating structures with (HS 89), show 
the RCA of 0.1 in aggregate level, while within the commodity level the tugs and pusher craft (8904) shows an RCA of 14, which is higher than the one. Another sector is (HS 97), works of art, collectors' pieces and antiques which in 2012 revealed a comparative advantage of 0.7 , while its constituent commodity with (HS 9705), which is the collection piece of the zoo, botanic and history which has the RCA of 7.

Table 4. Commodities with RCA greater than one $(\geq 1)$ in Sectors with Comparative Disadvantage in 2012.

\begin{tabular}{|c|c|c|c|c|c|}
\hline HS code & Sector accounts & RCA & HS Code & Commodity & RCA \\
\hline 89 & \multirow{2}{*}{$\begin{array}{l}\text { Ships, boats and other floating structures } \\
\text { works of art, collectors' pieces and } \\
\text { antiques }\end{array}$} & 0.1 & 8904 & the tugs and pusher craft (8904) & 14 \\
\hline 97 & & 0.7 & 9705 & collection piece of zoo, botanic, history & 7 \\
\hline \multirow{3}{*}{72} & \multirow{3}{*}{ Iron and steel with } & \multirow{3}{*}{0.5} & 7204 & $\begin{array}{l}\text { ferrous waste and scrap; remelting scrap ingots or iron or } \\
\text { steel }\end{array}$ & 2.4 \\
\hline & & & 7214 & $\begin{array}{l}\text { Bars \& rods of iron/non-al/s, nfw than forged, hr, } \\
\text { hd,/hot-extruded }\end{array}$ & 1.8 \\
\hline & & & 7223 & wire of stainless steel & 1 \\
\hline \multirow{2}{*}{10} & \multirow{2}{*}{ Cereals sector } & \multirow{2}{*}{0.5} & 1006 & Rice & 2.4 \\
\hline & & & 1007 & Grain sorghum & 1.8 \\
\hline
\end{tabular}

Source: Made from ITC export data

Refer to table 4, it shows among the export sectors with a comparative disadvantage while some of their commodities hold comparative advantages. Column one shows the HS code for sectors, column two are sectors, column three is an RCA for sectors, column four are commodity codes, column five shows specific commodities and the sixth column show the RCA for commodities

Iron and steel sector (HS 72) exhibit less the one RCA, but at commodity level it carries sufficient comparative benefits. Within this sector there are three commodities with greater RCA, which are ferrous waste and scrap; remelting scrap ingots or iron or steel (HS 7204), Bars \& rods of iron/non-al/s, nfw than forged, hr, hd, /hot-extruded (HS7214) and wire of stainless steel (HS 7223), demonstrated the RCA in 2.4, 1.8 and 1 respectively 2012. Furthermore, Rice (HS 1006) and Grain sorghum (HS 1007) in the cereals sector (HS 10) with RCA 0.5, revealed a comparative advantage of 1.9 and 2 which is above the accepted level.

\subsection{General Findings}

Revealed comparative advantage depicted several key issues about Tanzania exports by using data from UN Comtrade and International Trade Centre Exports. This paper used four (4) digit level of HS categorization for both years from 2009 to 2012 . The analysis portrayed that, Tanzania has a great comparative advantage through individual commodities which excels even in the sectors with comparatively disadvantaged. Many sectors show instability in its revealed comparative advantages compelled some of them to fall dramatically from the topmost level and lost their competence in the global market. Traditional products like coffee, mate spices and tie, together with tobacco and its ingredients are the only sectors that exhibited the increasing trend since 2009. They have been doing well in their commodity level by showing the positive trend.

On the side of commodities more than $50 \%$ did not manage to maintain its revealed comparative advantage, and some of them has a comparative disadvantage while others lost their export position value by decline amicably and move away from the top ten of the Tanzania export commodities. These include Gold, non-monetary (Excluding gold, ores Concentrates), Metalliferous ores and metal scrap, twine, cordage etc. and Sesame (Sesamum) seed. Moreover, other commodities like tobacco and tobacco manufacturers, power-generating machinery and equipment and Textile yarn, fabrics, made-up articles, n.e.s were able to enlarge their export performance and RCA value. The main distinguished point here is that, it is not so customary for commodities or sector to maintain its RCA when examined according to HS 4 digit level toward others in the world market. A sector with (HS 53), vegetable textile fibres, nes, paper yam, and woven fabric which has RCA in 26.0, appeared to have no comparative advantage in any of its commodities which makes it stand itself as a sector with RCA greater than one. In this case every sector in Tanzania which did not show RCA greater or equal to one accounted for $72 \%$ of all sectors, can be equipped, well through various resources to advance and intensify the country's export industry.

According to this analysis, Tanzania exported a total of 6253 products in the world market from 2009 to 2012 , averagely 1563.25 , but only $23.5 \%$ to $26 \%$ have been revealing comparative advantage to international market. The total average is decreasing every year as the data show that, in 2009 the total export were 1616, which decreased spontaneously to 1,179 exported products in 2012 , equals to $27 \%$ decline. In addition to that it has been realized that, the products with RCA which is greater than one also demonstrated the decline of its values in exports since 2009 from 400 to 353 in 2012, the decrease of $11.75 \%$, same to $2.9 \%$ each year. This is not good results for a country like Tanzania which has trade deficits (African Economic Outlook, 2013; Reuters, 2012) as it is supposed to increase and specialize more in export products while improving the internal market. Tanzania grasps the maximum opportunities in precious metal and manganese ores products as they have the highest RCA than any other product or commodities 


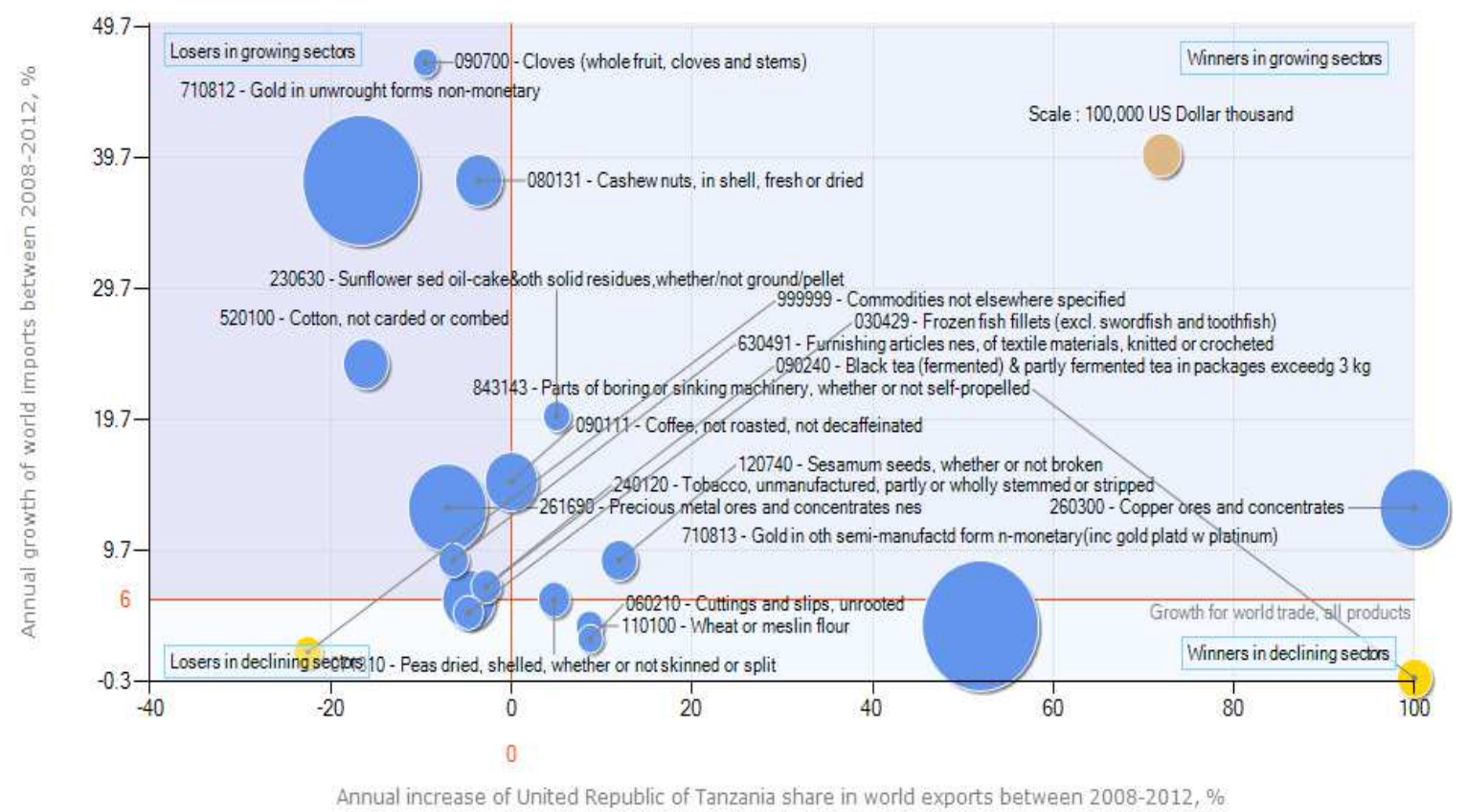

Figure 2. The growth of export products Supply in Tanzania and the International Trade from 2008 - 2012. (Source: ITC calculations based on UN COMTRADE statistics)

The clarification in figure 2 is as follows; The horizontal axis represents the Tanzanian share in the world exports for five years while the vertical axis represents the import growth globally for the previous five years while. Bubbles appear on the right side of vertical axis exhibit the commodities that Tanzania have RCA and is more specialized on its export. Yellow bubbles represent Tanzania as a net importer of that product while blue bubbles show Tanzania as a net exporter of that product. The reference bubble which is brown, represents bubbles which did appear due to lack of growth rate indicators. In addition to that the size of the bubble is proportional to export value. According to ITC User Guide, this chart is structural since the variation of prices does not have an impact in world imports ascribed in volume terms and there is no substantial disparity in the market.

\subsection{Recommendation}

According to the results of this analysis, Tanzania has revealed comparative advantage in various sectors and commodities, although most of them are basically dominated by primary products. This situation made the country to use many efforts to produce so as to earn more similarly or closer to industrialized nations. For more improvement in export sectors and commodities the following should be considered;

\subsubsection{Improvement of Sectors}

Tanzania has so many sectors with low or no comparative advantages while some of its constituent commodities revealed comparative advantage. Government should put much effort to sectors that portray highly comparative advantages by making sure that, they maintain or increase revealed comparative advantages by clearly evaluating the performance of each sector quarterly and providing technical and financial assistance so as to improve and remove the impediments in its structural changes. Also, depending on the global and environmental changes, different strategies should be set periodically in order to alleviate uncertainties which may affect the potency of the existing sectors and restore other sectors with no RCA. The government should set priorities which sector should be effectively empowered in a certain period depending significantly the needs of the domestic and the international market. Additionally, the government has to establish inter-sectoral export competition every year by analysing and enhancing the competence of domestic market, aiming at motivating and increasing the export rate and instituting market liberalization. All these will potentially have adverse positive effects on sectoral performance.

\subsubsection{Sectoral Policies}

Policies provide the directory, plans and or strategies on how to administer the activities or programs to attend the projected objectives. Tanzania government has set policies to govern and improve different economic sectors for the aim of alleviating poverty, improving living standard and increase the GDP. Example, the Agricultural and Livestock policy of 1997 (URT, 1997), aimed at rehabilitating and improving all agriculture infrastructures together with Trade policy 2003, aimed at enhancing Tanzania to establish and expand its economy in the highly competitive framework (URT, 2009). Many policies failed to reach its expected objectives due to different factors among them is lack of enough resource to facilitate the implementation of the policies. The government should set policies that are 
relevant to economic situation so as to accomplish the intended objectives in every sector in an efficient way. Policies should be well detailed and clarified, leaving no room for ambiguity and should focus much on how to counterchallenge the competition from other producers' countries by strengthening economic infrastructures.

\subsubsection{Establishment of Processing and Manufacturing Industries}

Tanzania is depending more on the export of primary products in the world market. In establishing industries within the production areas, the country will be able to produce more manufactured products in different qualities' depending on the existing market, which obviously will lower import dependence and increase the products and commodities in the internal market and for export as well. Also, it will create and increase the employments in the communities which will raise per capita income and the growth of the national GDP, by increasing the consumption of commodities and products which ultimately stimulate the growth for both industries. By establishing the processing industries as the first step toward the manufacturing industries, this will abridge the traditional methods of processing commodities which took a long time before exporting to the world market and it will stimulate other economic sectors like banking, agribusiness and insurances. According to UNIDO, (2012) manufacturing for export sector in Tanzania has been growing steadily from 2000 to 2005, and then augmented rapidly from 2006 up to 2010 compared to the sub-Saharan African and the world. It grows up worthily from \$ 129 million to $\$ 1904$ million accounted for an increase of $45 \%$ annum.

\subsubsection{Investing much in Agro Business}

Tanzania is one of the countries that depend much on agriculture as the engine of the economy and is one among the leading sectors that provide employment for more than $70 \%$ of Tanzanian (MAFSC, 2009). Mostly, the agricultural products in Tanzania are predominantly produced for food, reported about 65\% GDP in agriculture and for daily subsidiary [ibid]. Owing to that, the government should invest in agribusiness sector, which is main catalyst and underpin to industrial production and development. Many countries have managed to transform their economic and social structure by reforming agriculture sector with modern technologies. Through agribusiness it will help to improve the traditional farming system by expanding more areas for production, through introducing the regular crop cultivation (not rain based) by using technology and innovative farming system, which finally will increase the production of food for family security and arouse the economic welfare of the nation. Also, it will make the country to substantiate and accomplish the millennium goals for Tanzanian agriculture 'Kilimo Kwanza', which is to feed the whole population

\footnotetext{
${ }^{3}$ Kilimo kwanza - These are Swahili words which by direct translation means "Agriculture first", insisting on promoting the agriculture sector in the country.
}

and to produce for surplus. It will provide an opportunity for the society to learn the modern way of cultivation and strategies to maximize the agricultural benefits and monopolize both the internal and external markets. Nevertheless, the government should increase more Agriculture experts by increasing the enrollment in agriculture training colleges, increasing more agriculture universities than depending solely on Sokoine University, providing adequate subsidies to farmers and evaluate its performance annually, facilitating regular agricultural community education and to fortify agriculture annual budget and transparency upon its disbursement.

\subsubsection{Export Restriction to be Reduced}

Many countries in the world introduce import or export duties for different aims, but mostly to prevent the internal market for commodities or products from the foreign countries. These duties in one way or another have the impact on export for domestic producers and firms, as traders across the borders will have low demand for commodity export depending on the current market and the country general economic situation. Examples, for farmers to export their commodities outside Tanzania there are special taxes have to be paid. But different studies, like MAFAP, (2013), evidenced that those taxes have no benefit to farmers rather to add a cost burden on their shoulders, the fact that may compel the reduction of the export process. Therefore, the government to empower the export sectors in Tanzania by increasing the export rate, the policy makers have to know that introduction of taxes on export will always impede it, hence they have to restructure the export policies by making an intervention on different barriers to see how they can facilitate the export activities and also will not jeopardize the whole export system by discouraging the impetus for individual producers and firms.

\subsubsection{Attracting more Foreign Direct Investment (FDI)}

Foreign Direct Investments, provide an opportunity for the country to receive foreign investors in different sectors of the economy. For a country like Tanzania to improve its export performance, it has to invest much in manufacturing sectors, since in manufacturing products has less comparative advantages for a long time. By inviting and attracting FDI in manufacturing sectors, Tanzania will be able to produce more manufactured goods to be sold domestically and for export, which will act as a vehicle to produce more commodities in different sectors. Other expected influence from FDI includes the technology transfer, employments and competitive human capital workforce. Human capital is a very important aspect of production as it contains the knowledge and experience related to different sectors which is intended to increase the expected value (Mwasha, 2013). Additionally, the increment in FDI will expand the Tanzanian market, including among others East African Community market, Southern African Development Community (SADC) market, the European Union and AGA in USA. Therefore Tanzania has to use effectively the partners market especially nearby countries 
which will cost, fewest amount in export and also provide the chance for small business to grow as they can exchange trade and services through boarders which ultimately increase the national revenue and increase per capita income.

\subsubsection{Strengthening the Currency and Controlling Inflation Rate}

Tanzanian shillings (TSH) have been depreciating considerably against the United States Dollar (USD) which is used as the main base currency for international exchange in Tanzania. This has been influenced by many factors, but the trade deficit, which is accompanied by higher import than export hold the great portion. The government has been devaluating the currency since 1986, at that time aimed at allowing the protected sectors to acclimatize to market impetus since TSH have been manipulated much by market demand and supply (Maehle et al, 2013). But also the policies that govern the exchange rate system is not well implemented, as there are mushrooming of exchange rate centre's and black market for foreign exchange (Morris, 1993), which in my understanding become difficult for the government to control so as to have a uniform exchange rate. Also, some of the big shops and supermarkets have introduced the dollar system in shopping. All these factors weakened the currency (TSH) which ultimately reducing the purchasing power in the international trade. On the side of inflation rate, Tanzania is facing the problem of production resources such as machines and it's peripherals which most of them are imported expensively from abroad and power sources which currently depending on electric current which is not reliable but also expensive. The importation of fuel and gas from outside also is very expensive. All these will augment the commodity prices and other services led to the rise of inflation. High inflation rate attributed to higher interest rate which will always deteriorate the domestic currency. This situation will have the adverse impact on exports in the world market. Therefore the government should work hard to combat the inflation rate and control the exchange rate system which is the potential factors for restructuring export.

\subsection{Direction for Future Research}

The analysis of Tanzanian revealed comparative advantage have uncovered important areas which need further studies for the development of export and improvement of quality and quantity products and commodities in the world market. The following areas need the comprehensive studies;

Many sectors average $72 \%$ demonstrate comparative disadvantages where as out of a total average of 1563.25 products exported for 4 years is only an average of $26 \%$ have comparative advantage. These results are not imperative potential for the growing economy like Tanzania. Research is needed to be conducted intensively to examine and analyse the main source of the problem, Tanzania has abundant resources and has portrayed potential features that it can compete well in international market, but is only few sectors and commodities managed to compete, while as the time elapses most of them lose their export and RCA value. Also, the study has to provide the framework on which measures should be taken by government and communities to restore sectors and commodities which lost their RCA how to gear them up and maintain the emerging one.

Also the analysis discovered that, some sectors have the highest comparative advantage while its constituent commodities does not have, at the same time some commodities has RCA while in its aggregate level has comparative disadvantage. The study has to examine the influential factors for that situation, how does the RCA in aggregate (sectoral) and commodity level can affect each other and what will be its impact in the economy.

Furthermore, together with the greatest effort which have been employed by the government to improve the export sector by establishing two economic zones, the Export Processing Zones (EPZs) act 2002 and Special economic Zones (SEZs) (URT, EPZA (2006), the analysis exhibit that, the number of exported products in HS 4 digit level is decreasing significantly at an average rate of $2.9 \%$ every year accompanied by higher fluctuation rate in export value. Research is needed to determine the influence or impact of exchange and inflation rate to the decline of the export and to what extent does these two variables affect the export.

Another important area to be studied is that, to what extent does the policies in every sector together with export policy affects the domestic production and export rate to the world market. Governments create and establish rules and regulation to govern specific programs and provide the framework on how social economic activities can take place. Include among others, the government policies that my affects the trade, welfare, including export are tariffs, duties, taxes, quota and other export restrictions. Reference to Bonarriva et al, (2009), by considering which kind of restriction will be employed; it will either reduce the volume of export or impinge on export prices which ultimately will denature the whole export process. Therefore, further study is needed to elucidate how does this policy affect the production and export and to suggest the valuation measures that will stimulate export led economy which will reduce the current Tanzanian trade deficit.

\section{Conclusion}

This paper analyses Tanzania Revealed Comparative Advantage in different sectors and commodities by using HS 4 digit commodity level, using export data from UN Comtrade to examine the comparative advantage of the top ten export commodities in Tanzania and International Trade Centre (ITC), which provide export data for both sectoral performance and its commodities. According to the analysis, Tanzania export performance is subsequently increasing in collaboration to its Revealed comparative Advantage as it was found that there was only two commodities which had higher export value with less than one RCA namely 
Medicinal and pharmaceutical products and Special transaction not Classified. Also Tanzania demonstrated concurrently from 2009-2010 that it has abundant mineral resources such as gold, Metalliferous ores and metal scrap as a leading export sector. Tanzania has a strong comparative advantage in these commodities in the world market accompanied by other commodities which was analysed in this paper. The important things the government should do is to make the potential plans after the disappearance of these minerals as most of them are non renewable, what other sources of export will replace these leading sectors. Also the government should initiate the projects which will cover the position of these minerals after it's vanishing. Policies regarding mineral sector should be well detailed and more focused on the best ways to make mineral industry more competitive with other producer countries. The agreements to invest in these sectors and others must be open and the societies around the investment areas have to be involved in policy making and how the investment is going to benefit the surrounding communities.

\section{Acknowledgements}

The authors would like to express their great thanks and appreciation to Mr. Wen Peng (Supervisor) for his advice about writing this article and Mr. Wei Wei (Course tutor) for his support upon the accomplishment of this article.

Likewise, we are indebted to Mr. Salimu Abushiri Jinyevu as the first reviewer and his comments towards the improvement of this oeuvre.

\section{References}

[1] African Development Fund, (2007), Project completion reports (PCR) of Structural Adjustment Loan (Sal); Republic of Tanzania; Governance, economic and financial reforms department, March 2007.pp 02-16

[2] African Economic Outlook, (2002), Tanzania; OECD/ AfDB, 2002; pp 279-290. (Online) available: http://www.oecd.org/countries/tanzania/1826462.pdf

[3] African Economic Outlook, (2013), Tanzania http://www.africaneconomicoutlook.org/fileadmin/uploads/a eo/2013/PDF/Tanzania\%20\%20African\%20Economic\%20 Outlook.pdf

[4] Bariyo, N. (2013), Tanzania 2012 Gold Export Earnings Drop 3\% on Year - Central Bank. (Online) Available: http://www.euroinvestor.com/news/2013/02/20/tanzania-201 2-gold-export-earnings-drop-3pct-on-year-central-bank/122 16199 (February 20, 2013)

[5] Batra, A., \& Khan, Z. (2005), Revealed Comparative Advantage: An Analysis for India and China: Indian Council for Research on International Economic Relations; WORKING PAPER NO. 168; India Habitat Centre, New Delhi

[6] Bigsten, A. \& Danielsson, A. (1999), Is Tanzania an Emerging Economy? A report for the OECD project" Emerging Africa", Sweden. pp 08-24
[7] Bonarriva, J. Koscielski, M. \& Wilson, E. (2009), Export Controls: An Overview of their Use, Economic Effects, and Treatment in the Global Trading System; International Trade Commission, working paper no. ID - 23, USA, p. 06-10

[8] Brylinsky, T. (1996) Structural Adjustment, the Environment and Sustainable Development: Under what conditions will 'sensible' economic policies have unintended social, economic, and environmental consequences?" Case of Tanzania, (London: Earthscan, 1996):107 - 127.

[9] Chingarande, A., Mzumara, M., \& Karambakuwa (2013), Comparative Advantage and Economic performance of East African Community (EAC) Member States; $J$ Economics, 4(1): 39-46(2013).

[10] CIA (2014), The World Factbook; Tanzania. (Online) Available:

https://www.cia.gov/library/publications/the-world-factbook /geos/tz.html

[11] Dixit, A. \& Norman, V. (2002), Theory of International Trade; Shanghai University of Finance \& Economic Press. p. 01-05

[12] Eifert, B., Gelb, A. \& Ramachandran, V. (2005), Business Environment and Comparative Advantage in Africa: Evidence from the Investment Climate Data: Centre for Global Development; Working Paper Number 56, February 2005. pp18- 27

[13] Economy Watch (2010) Tanzania Trade, Exports and Imports: (Online) Available: http://www.economywatch.com/world_economy/tanzania/e xport-import.html

[14] Foxley, A., (2009) RECOVERY; the Global Financial Crisis and Middle-Income Countries: Carnegie Endowment for International Peace, Massachusetts Avenue, NW. p. 18-25

[15] Hill, C., W. (2008) International Trade Theory, sixth Edition, Published by McGraw - Hill Companies, Inc and Posts \& Telecom Press. p. 44-106

[16] Investors Guide to Tanzania: Tanzania Investment Centre; Available at http://www.tic.co.tz/media/2013-TIC-Investment-Guideboo k_2.pdf

[17] INVESTMENT OPPORTUNITIES AVAILABLE IN TANZANIA: Online Available at http://www.mit.go.tz/pdf/AREAS\%20OF\%20COOPERATI ON\%20BETN\%20TZ\%20AND\%20GERMAN-

[18] Isaac, S. \& Othieno, L. (2011) Uganda's Revealed Comparative Advantage: The Evidence with the East African Community (EAC) and China; EPRC, Towards Sustainable Development; First draft, February 2011.pp. 01

[19] ITC User Guide,-, Trade Competitiveness Map: Benchmarking national and sectoral trade performance; Market Analysis and Research Division of Market Development; Trade Performance Hs International Trade Centre

[20] ITC, - Trade Competitiveness Map; Analyse Country and Products Competitiveness with Trade Flows. (Online) Available:

http://legacy.intracen.org/appli1/TradeCom/TP_EP_CI.aspx $? R P=834 \& Y R=2009$ 
[21] Jerving, S. (2013) Tanzania Concerned Gold Slump May Prompt Mines to Shut; Bloomberg Sustainability. (Online) Available:

http://www.bloomberg.com/news/2013-04-16/tanzania-conc erned-gold-slump-may-prompt-mines-to-shut.html (April 17, 2013)

[22] Jurčić, L., \& Teodorović, I. (2011) Global Crisis, Recovery and the Changing World: Ekonomski Pregled, 62 (5-6). pp. 233-247

[23] Krugman, P., R. \& Obstfeld, M. (2006) International Economics: Theory and policy; $7^{\text {th }}$ edition, published by Pearson Education Asia Ltd. p 4-205

[24] Lange, S. (2008) Land Tenure and Mining in Tanzania; CMI Report. (Online) Available $\mathrm{http}: / / w w w . c m i . n o / p u b l i c a t i o n s /$ file/3008-land-tenure-and-m ining-in-tanzania.pdf

[25] Lunogelo, H.B., Mbilinyi, A., \& Hangi, M (2010) Global Financial Crisis Discussion Series; Paper 20: Tanzania Phase 2; Overseas Development Institute, 111 Westminster Bridge Road, London, p 01-07

[26] Maehle, N., Teferra, H. \& Khachatryan, A. (2013) Exchange Rate Liberalization in Selected Sub-Saharan African Countries: Successes, Failures and Lessons; International Monetary Fund, working paper /13/32, pp. 39-45

[27] MAFAP, (2013), Review of food and agricultural policies in the United Republic of Tanzania. MAFAP Country Report Series, FAO, Rome, Italy. pp. 52-65

[28] Morris, S. (1993), Inflation dynamics and the parallel market for foreign exchange; Journal of Development Economics Vol. 46 (1995),pp. 295-316

[29] Muchanyuri, B. \& Mzumara, M. (2013), Inter-Sectoral Comparative Advantage of Tanzania and Impact on International Purchasing: Greener Journal of Business and Management Studies; Vol. 3 (8), pp.361-368.

[30] Mwasha, N., A. (2013), An Over-view of Online Recruitment: The Case of Public and Private Sectors in Tanzania; European Journal of Business and Management, Vol.5, No.32, 2013. pp. 11-21

[31] Mzumara, M., Chingarande, A., \& Karambakuwa, R. (2012) An Analysis of the Revealed Comparative Advantage in Southern African; Journal of Sustainable Development in Africa (Volume 14, No.8, 2012). ISSN: 1520-5509. pp 50-74

[32] Pearson, S., R \& Meyer, R., K. (1974), Comparative Advantage among African Coffee Producers. American Journal of agricultural economics; Volume, 56 (2): pp 310-313

[33] Portstrategy, (2013) Tanzania Shake-up. (Online) available: http://www.portstrategy.com/news101/insight-and-opinion/p ost-script/tanzania-shake-up

[34] Pugel, A., T. (2005): International Trade, 12th Edition. Published by McGraw-Hill Education (Asia Co.) \& China Renmin University Press. p. 17-149

[35] Reuters (2012), Tanzania Trade Deficit Double due to oil demand (June 5,2012). (Online) Available : http://www.reuters.com/article/2012/06/05/tanzania-deficit-i dAFL5E8H596M20120605

[36] Serin, V., \& Civan, A. (2008), Revealed Comparative Advantage and Competitiveness: A Case Study for Turkey towards the EU. Journal of Economic and Social Research 10(2) 2008, 25-41

[37] Tanzania Bureau of Statistic (2012) Population and Housing Census 2012: (Online) Available: http://www.nbs.go.tz/sensa/new.html

[38] TIC, Prime minister's Office, (2013).Tanzania investment Guide 2013-2014.pp 07-16 (Online) Available: http://www.tic.co.tz/menu/179

[39] UNIDO, (2012), Tanzania Industrial Competitiveness Report 2012; Ministry of Industry and Trade of the United Republic of Tanzania (MIT), pp 29-29

[40] UN comtrade, (2010) United Nation Commodity Trade Statistics Database. (Online) Available: http://comtrade.un.org/db/

[41] URT, (2003), National Trade Policy; Trade Policy for a Competitive Economy and Export-Led Growth, Ministry of Industry and Trade, Dar es Salaam, pp. 15-21

[42] URT, (2009), Tanzania Trade Integration Strategy, 2009-2013; Ministry of Industry, Trade and Marketing, pp 10-13

[43] URT, Prime Minister's office (----) Investment Potentials and opportunities in Agriculture: Tanzania Investment Centre

[44] URT, MA F S C (2009) INVESTMENT POTENTIAL AND OPPORTUNITIES IN AGRICULTURE (CROP SUB-SECTOR); (Online) available http://www.agriculture.go.tz/highlights/AGR\%20POTENTI AL\%20REVISED\%20NEW\%20VERSION\%20Final-2-\%2 0NEW.pdf

[45] Wangwe, S., M. (1996) Economic reforms and Poverty Alleviation in Tanzania; Employment paper 7, Employment and training Department, International Labor Office Geneva

[46] Wizara ya Uchukuzi (2011), Taarifa ya Miaka 50 ya Uhuru wa Tanzania Bara (1961- 2011), (Desemba 2011), pp. 32-46

[47] Wobst, P. (2001) Structural Adjustment and Intersectoral Shifts in Tanzania; A Computable General Equilibrium Analysis: Research Report 117, International Food Policy Research Institute, Washington, D.C 